Images in...

\title{
Breast augmentation with collagen injections
}

\author{
Lucinda Tullie,, ${ }^{1}$ Loubna Charkaoui, ${ }^{1}$ Wail Al Sarakbi, ${ }^{1}$ Ali Sever ${ }^{2}$ \\ 1Surgery Department, Maidstone and Tunbridge Wells NHS Trust, Maidstone, UK; \\ 2Radiology Department, Maidstone and Tunbridge Wells NHS Trust, Maidstone, UK
}

Correspondence to Dr Lucinda Tullie, Itullie@doctors.org.uk

\section{DESCRIPTION}

A 38-year-old South-East Asian lady presented to breast clinic with a right peri-areolar breast lump. She denied any history of breast disease, breast surgery or significant family history. Examination revealed nodularity in the upper outer quadrants of both breasts and a more discrete right breast lump suggestive of a cyst. The impression was of fibrocystic disease, a common occurrence in this age group of women. Bilateral mammograms were performed (figure 1) which showed significant changes from those taken in 2009 following a presentation with right mastalgia (figure 2). Further questioning revealed that 12 months prior, she had collagen injected into her breasts to provide uplift and firming. This was brought into the UK from the Philippines and injected by a friend, who was inexperienced in this field. Such practice is common throughout Asia, particularly the Philippines. Collagen, in the form of recombinant human or bovine collagen, is one of the most commonly used fillers for soft tissue augmentation. ${ }^{1}$ Although histological evidence of collagen in soft

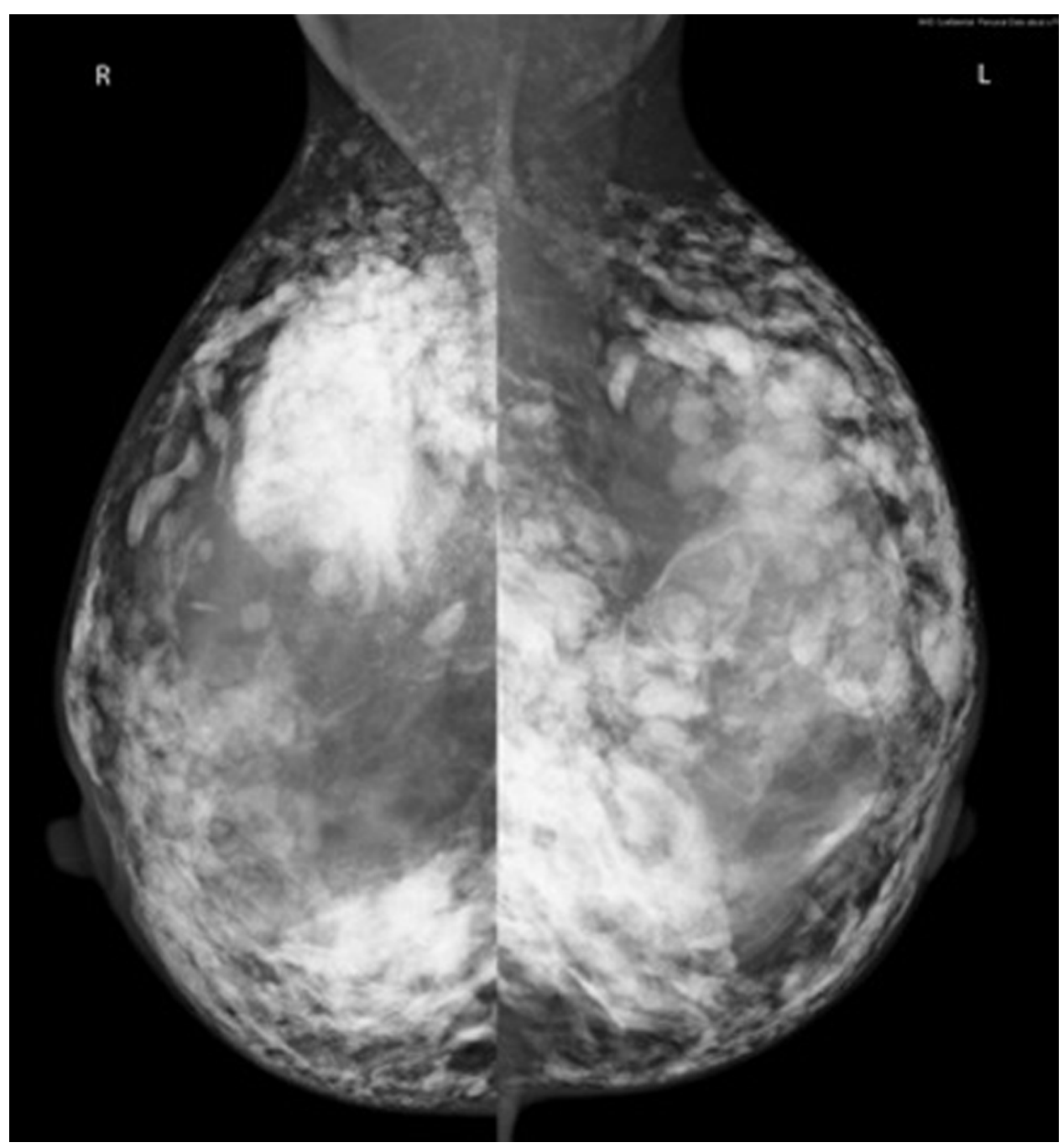

Figure 1 Multifocal increased densities with a rounded nodular appearance consistent with injection into both breasts. 


\section{BMJ Case Reports}

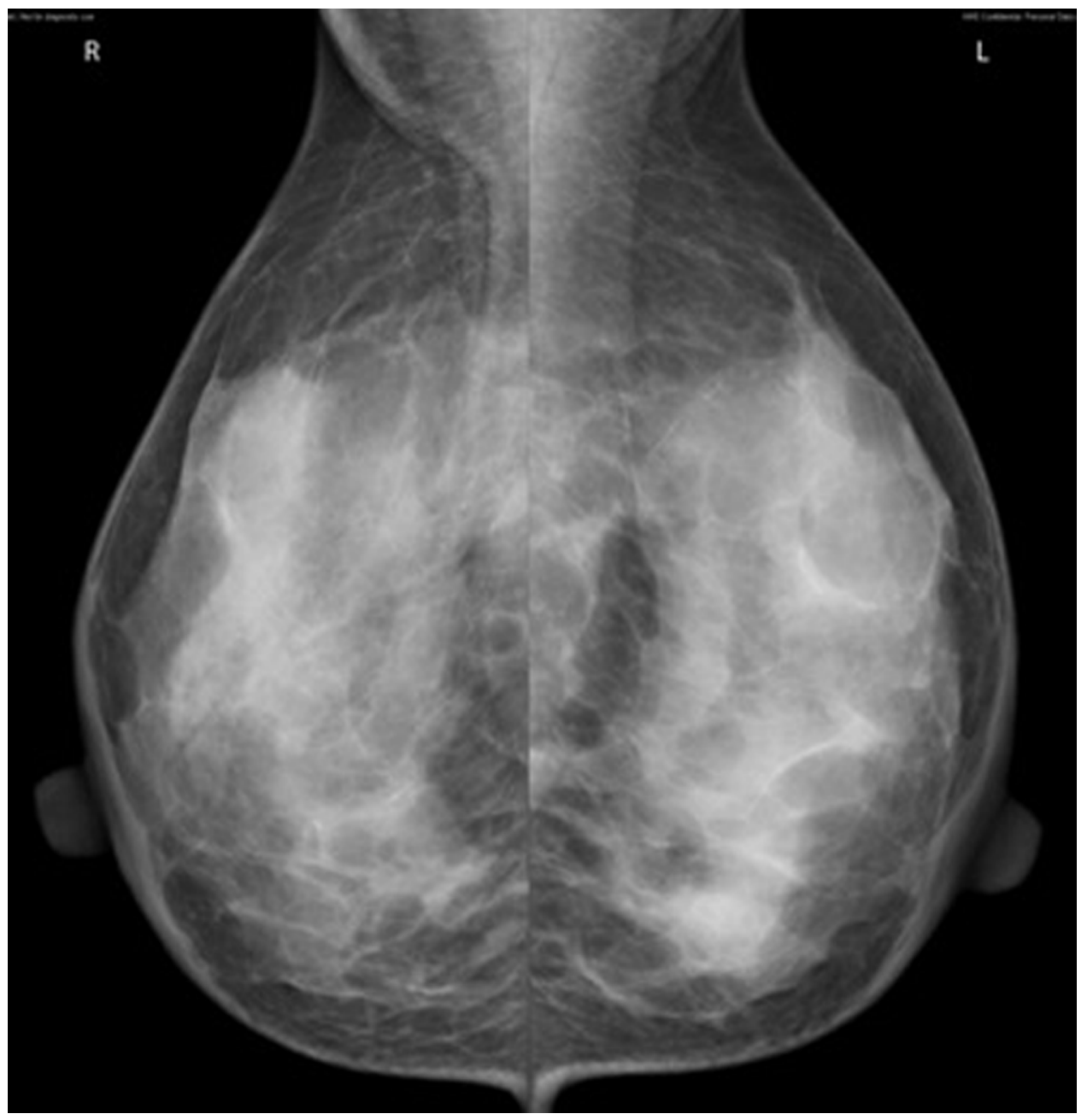

Figure 2 Moderately dense glandular breast tissue with no focal abnormality.

tissue disappears 6 months postinjection, ${ }^{2}$ no literature evidence exists documenting long term effects of its use in the breast, especially in the case of injection in inexperienced hands. In light of this, we intend to follow-up and re-image the patient in 1 year. With awareness of this practice, it is important that we are able to recognise the appearance of collagen on mammography and be vigilant of how such appearances may obscure underlying abnormalities, possibly reducing the sensitivity and specificity of breast screening.
Acknowledgements Many thanks to Mrs Susan Jones for her expert help and guidance.

Competing interests None.

Patient consent Obtained.

\section{REFERENCES}

1. Klein AW, Elson ML. The history of substances for soft tissue augmentation. Dermatol Surg 2000;26:1096-105

2. Lemperle G, Morhenn V, Charrier U. Human histology and persistence of various injectable filler substances for soft tissue augmentation. Aesthetic Plast Surg 2003;27:354-66. 


\section{BMJ Case Reports}

This pdf has been created automatically from the final edited text and images.

Copyright 2011 BMJ Publishing Group. All rights reserved. For permission to reuse any of this content visit http://group.bmj.com/group/rights-licensing/permissions.

BMJ Case Report Fellows may re-use this article for personal use and teaching without any further permission.

Please cite this article as follows (you will need to access the article online to obtain the date of publication).

Tullie L, Charkaoui L, Al Sarakbi W, Sever A. Breast augmentation with collagen injections. BMJ Case Reports 2011;10.1136/bcr.06.2011.4387, date of publication

Become a Fellow of BMJ Case Reports today and you can:

- Submit as many cases as you like

- Enjoy fast sympathetic peer review and rapid publication of accepted articles

- Access all the published articles

Re-use any of the published material for personal use and teaching without further permission

For information on Institutional Fellowships contact consortiasales@bmjgroup.com

Visit casereports.bmj.com for more articles like this and to become a Fellow 